\title{
Transfiguration of Man and Struggle with Passions in Due Holy Father Heritage (Maximus Confessors' Doctrine)
}

\author{
Sergei N. Belkov* \\ Russian Christian Humanitarian Academy \\ 15 nab. River Fontanka, St. Petersburg, 191023, Russia
}

Received 16.08.2016, received in revised form 20.09.2016, accepted 21.10.2016

\begin{abstract}
Maximus Confessor, concerning mystical divinity, symbolically identifies the concept "passion" with the concept "deification". Here sense of passion as suffering and endurance and passion as natural internal-energy characteristic of the human nature extremely approach. In this case the endurance appears in especially positive sense: as "patience" of influence of the fertile Divine gifts streaming to the person. On the other hand, natural internal-energy of a human nature also proves here in ideal sense - a passionate tendency to God, to connection with Him.
\end{abstract}

Keywords: Maximus Confessor, suffering and passion, theosis.

DOI: 10.17516/1997-1370-2016-9-12-2896-2903.

Research area: politology.

Being compelled, for obvious reasons, somehow to limit a subject field of our research and addressing to Holy Father Heritage, we intentionally focus our attention on the doctrine of Maximus Confessor. His anthropology is not organic only for Christian theology, but it is also distinguished by its amazing integrity and details' development. Furthermore, Maximus Confessor possesses a merit of implementing a creative synthesis of the Christian anthropological concepts preceding his works.

Following Holy Fathers' tradition, Maximus Confessor defines man as a complex, dialectic and contradictory unity of soul and body. According to Ioann Meyendorf, 'this dual human nature is not simply a static imposition of two heterogeneous elements that are a mortal body and an immortal soul on each other, but a reflection of a dynamic function of man which is shown concerning God and the mortal plain"1. Relying on the idea, widely known in antiquity, about macrocosm and microcosm, Maximus Confessor defines man as 'the small world in big', i.e. as the microcosm uniting the world of spirit and the world of a body, intelligible world and sensibilia in itself ${ }^{2}$. Every person belongs to each of these worlds with his/ her soul and body, and therefore both of these worlds, being different outside of a person, find a real unity in humanity. But Maximus Confessor attaches a fundamentally different meaning

(C) Siberian Federal University. All rights reserved

* Corresponding author E-mail address: belkov@sapernoe.ru 
to the antique idea of unity of microcosm and macrocosm: man in his anthropology acts as the center of all divine creation, he settles down in its center, and the task of association and solution of all contrasts of the created world allotted to him by the disposition of Providence. Man is assigned to implement this great goal and, therefore, in its creation he has a special, exclusive status. In particular, this is expressed in a special intimacy of a human being to God compared with other beings.

This idea of a special, exclusive status of man in Creation corresponds finely to the bible idea, according to which man is a Lord of creation and is created in compliance with an image and likeness of God. But in Maximus Confessor's anthropology, 'image' and 'likeness' are determined by different definitions. Upon the time of creation of man, God endowed him with four personal qualities, such as genesis, eternity, goodness and wisdom. And if the first two - genesis and eternity - represent an 'image' of the divine genesis, the third and the fourth goodness and wisdom - should be addressed to the 'similarity' of the human and divine genesis which is reflected, at the level of man, in his moral virtues.

Since man is, in its essence, 'an image and likeness' of God, this supposes not only the fact that he is not entirely sincere with God, but also the fact that he has a special mission, which is expressed in the idea of association of all created. But in order to execute this mission and to unite all of the created world by himself, man, constituting a microcosmic similarity of a macrocosm, first of all, has to overcome his own separation, achieve an internal unity of parts of his being, connect all of his opposites. Maximus Confessor emphasizes five 'divisions' of a human nature, which namely constitute an anthropological characteristic of a person. The first 'division' is a contrast of God and Creation of the World, this 'division' is for the created and uncreated nature. The second division is a contrast between the heavenly and the terrestrial, the third division is devoted to the contrast between the intelligible and the perceptible. The fourth contrast concerns Adam's exilement from the Paradise, and the last, fifth, contrast is a division of a human nature into two genders: male and female.

According to this human mission, the special anthropological program of self-enhancement is shaped, which is the ending with deification of man in perspective. The five stages of doing so assume, firstly, overcoming a biological division of a human nature into male and female; secondly, the union of the environment of an ordinary human existence with the Paradise, i.e., the transformation of all the Earth into the Paradise; thirdly, the association of the intelligible and sensuous worlds, followed by the association of the terrestrial and heavenly reality, having accomplished by that what a person will not differ from angels anyhow. At last, having overcome the last 'division', the person receives from God everything what God owns due to the divine nature, i.e. finishes the deification himself and the entire created world.

The problem of struggle against passions in the anthropological doctrine of Maximus Confessor should be considered in this aspect. The power of passions over a person is the power of the sinful founding. Passions arise with Adam as a result of his fall and extend further to the entire human race, 'the sin entered a human nature through a crime [Adam's], and through a sin - the passion inherited since birth'. ${ }^{3}$ From the moment of the fall 'the passion merged with the $\sin$ through the origin corresponding to pleasure, becomes the center of demonic forces and their effect on a person in all cases ... All sinful passions develop in reaction to two main tendencies of passion, such as a search for pleasure and an escape from sufferings which 
act separately or jointly's. Man is defenseless towards demonic forces due to the existence of a passionate beginning in his being after fall; it recedes before their impact and reduces the will before the power of various pernicious passions. According to Maximus Confessor, 'by means of them [passions] any crafty force worked, by vehemence of a nature inducing the will through natural passions [address to] to decay unnatural passions's.

At the same time there are absolutely different attributes of the understanding of passion in Maximus Confessor's tractates, where attribution of human natures' passion is qualified as positive, i.e. passions are capable to play a certain soteriological role. In Ambigua in the context of reasoning on the deification, Maximus Confessor considers this concept in connection with the concept of passion, 'What can be more long-awaited for worthy people than the deification in which God, joined with others who become gods, makes everything divine as $\mathrm{He}^{96}$. There are various symbolical comparisons of soul at the deification and some emotional conditions of a human nature, such as 'pleasure', 'enjoyment' and even 'passion'. 'In general and in a general sense, the passion of the human being is what the pleasure or grief follows - after all the passion is followed by grief; and passion is not grief because the insensible, undergoing, doesn't feel pain'?

Such an understanding of passion, which is most often negatively estimated in the orthodox patristic ascetic tradition, comes to the end at Maximus Confessor's works with the doctrine about the highest passion of a human nature as about that quality of the last which eventually leads man to the unification with God. Such a circumstance can once again serve as a basis in favor of Maximus Confessor as the most important representative of the doctrine about passions that is relevant for the patristic tradition.
It is necessary to pay attention in Maximus Confessor's doctrine, firstly, to a specific anthropology of passions, the doctrine about how a predisposition of a person to passions is connected with the very human nature which was created in the beginning by God and owing to this fact borrowed the divine grace, but then, after disobedience in the Paradise, it was damaged and captured in the slavery of an initial sin. In the context of such a perspective one is bound to ask a question depending on the fact, whether passions are something absolutely foreign to a human nature, introduced in it from the outside by means of a sin, or whether passions are implanted in a nature of the person, ontological and express those potentialities in the distorted look which were put by the Creator to the person. The quotes of Maximus Confessor given above, on the one hand, testify that he, as well as all Fathers of Church, understood passions as an abnormal and pernicious phenomenon against which it is necessary to fight and which is necessary to be won. At the same time, in Maximus Confessor's works it is simple to find fragments where the concept of passion is used as a neutral concept, and sometimes as a positive one. Such ambiguity needs special explanations.

It is necessary to consider that circumstance, which in many respects of the patristic traditions' understanding of passions is similar to the understanding of passion at philosophical Hellenism schools. Maximus Confessor's works aren't an exception. Aristotle allocates ability to undergo something burdensome and trying by a special positive value. The one "who makes what and for something should be, as it should be and when you should do it, and, consequently, fears and demonstrates prowess, that is courage, because the manly suffers and acts honorably and as [orders right] judgment. Meanwhile, the purpose of any activity is that, which corresponds to the [moral] foundations, i.e. courage is good 
for the manly, and that is the purpose of courage, because each subject is determined according to its purpose. So, moral perfection is the purpose for which the courageous makes and commits its rightful courage' ${ }^{8}$. Such endurance must be connected with virtue, and following the Aristotle, John of Damascus emphasizes the rootedness of passions in the basis of human nature. 'In general, and in a general sense, passion of a living being is what a pleasure or sorrow should be, that is because the passion is followed by a sorrow; and the passion is not sadness because the insensible undergoing does not experience pain'9. Such a "rational understanding" of passion has no traditional negative values of ascetic practices yet. Maxim Confessor also highlights the relationship of passion with an inevitable impact on human nature of external influences. "Having heard 'the passion', one should understand that [the word] wisely, because it means 'passion' not in the sense of transfiguration or decay here, but [the meaning of] inherent in the nature of an existing one. For all that had led in Genesis, is movement, not as self-motion or self-force"10.

The passions' understanding of science literature,particularlyinmedicaltreatisesofGalen, has had some influence on the patristic concept of passions. 'The passion is the unreasonable movement of soul because of representation of the benefit or the evil. The representation of the benefit excites desire and representation of the evil - anger"11. It is necessary to notice that in such definitions the passion doesn't contact with the sin only, and the desire and the anger don't mean negative sides of a human nature, but such souls' powers, which are initially given by God to man. There is desire and anger in a similar sense in Maximus Confessor's works, 'The passionate part of soul is divided into that, which submits to reason, and that, which doesn't submit to reason... And that one which submits to reason is divided in two parts, namely, the passionately desirable and the outraged; submitted to reason; it is peculiar to go reason and to submit to it. Then the passionately desirable divides into pleasure and grief. Because desire, being satisfied, makes pleasure, but it isn't satisfied that is grief ${ }^{\prime 2}$. Thus, in Maximus Confessor's works, as well as in the works of many other Fathers of Church, the passion can mean quite a natural movement of the unreasonable part of a human nature and if the reason is capable to direct this movement, "the passionate part of soul' can play an essential role in the realization of a divine plan about man. If this movement remains unreasonable, the human nature will be fated to remain in the captivity of a fall of man. In other words, passions have an essential contact with a human nature and are present at it even before a fall, but don't appear together with a fall. It is especially important to emphasize that according to Maximus Confessor, as well as to the whole patristic tradition, the natural beginning is identical to the paradise state, and the sin is a distortion, an evasion from it. Therefore, passions characterize a human nature from the moment of creation of man.

Therefore, the struggle against passions and victory over them cannot mean their final extirpation. 'Struggling with passions should not eradicate a natural power [ability of a nature] together with passions: that agrees with a natural power [with possible on a nature], should be kept $^{13}$. The ontologic status of passions is more difficult and problematic than can be seemed at first sight; and therefore there is a doctrine about something like 'mechanism' of realization of the passionate beginning in the patristic tradition, where the struggle against sinful passions appears as a necessary, but not a final stage of this realization.

One more essential moment is the division of soul into two parts - reasonable and unreasonablewhich goes back to Aristotle. 'One part of soul has no judgment (alogon), the other one possesses 
it (logon ekhon). Whether they are differentiated, like parts of a body and everything that has parts, and by the nature they are inseparable as camber and concavity of a circle - for the real research it has no value. One part of that is deprived of judgment, probably, the general [for all live], i.e. physiological (to phytikon), I mean the reason of assimilation of food and growth - such an ability (dynamis) of soul can be believed in all that acquires food, including in germs, and it is the same ability, as in adult [beings]; it after all is more reasonable, than to believe in the latter case some other [ability to the same] ${ }^{114}$.

And further one more explanation follows, 'Thus, the part of soul deprived of judgment is disyllabic too. One part is physiological - in any relation doesn't participate in judgment, the other part is the subject to an inclination and generally striving (epithymetikon kai holös orektikon) - in some sense it is involved so far as it is obedient to judgment and obeys it. So, when we say, 'there is a judgment of the father and friends', we mean the relation, but not what happens in mathematics. We mean that the part of soul deprived of judgment in some sense submits to judgment, explanation, and any charges and encouragement let us know that. If it is necessary to recognize that this part of soul has judgment, then the part having judgment will be disyllabic, i.e. on the one hand, it [possesses it] in the true sense and itself, and on the other hand, it is something, obeying [judgments as the child] the father ${ }^{15}$.

So there is an idea, very important for the later patristic tradition, of a structure of man's mental world. The soul is subdivided into reasonable and unreasonable parts. The latter includes a part that is subject to the mind, and the part which is beyond it. Later in ascetic traditions the part of the unreasonable soul dependent on reason is named as a sensual-longing soul. The part of unreasonable soul, which is not dependent on reason, corresponds to that what Aristotle calls physiological soul. Later, within Christian culture, the idea of this part of soul will become more volume and will include all physiological aspects of mental activity. The ideas of part of unreasonable soul, which is not dependent on reason, correspond to the doctrine about affects; since, in accordance with the law, an act committed in the heat of passion, is an uncontrollable act, and people cannot be responsible for it.

So, the part of the unreasonable soul dependent on reason is a component of a mentality structure which plays the most important role in the patristic doctrine about the struggle against passions. There are psychic forces in this part of the soul that can manifest itself in two ways. If reason control over this part of soul remains, for example, the desire is proved as a natural aspiration to pleasure as a desire to possess the missing, and anger goes to everything that by the nature of adequately fair indignation. But the same forces can manifest themselves negatively, when the mind ceases to dominate them. In that case the desire turns into lust, aspiration - to pleasure of $\sin$, and the anger is expressed in the desire for revenge and is proved in unjustified rage and unreasonable hatred. This deviation is also a source of sinful passions, the unnatural basis of their manifestation which arises owing to human disobedience to God, in the disobedience, in which a human soul is shown as an activity of the unreasonable 'passionate' part of the soul acted against one's better judgement.

Desire and anger are considered to be two root passions whereas all other sinful passions are, to some extent, their modifications. Classification of passions, typical of the patristic tradition, includes eight modifications, which are gluttony, fornication, greed for money, anger, grief, despondency, vanity and pride. The named passion is subdivided into corporal and mental; however from all aforesaid it has to be clear that such a division is very conditional and all 
passions are 'the unnatural movement of soul' on the origin, i.e. have a sincere origin. Any passion is a deviation from God's plan about man, and this deviation in sincere life though the plan of the Creator can extend in one case to a corporal shape of man, in the other case - on his inner world. When such a deviation happens, the corporal constitution of man doesn't also remain indifferent and acts as the accomplice of soul in its sinful aspirations.

The most important conclusion of the patristic doctrine about the struggle against passions consists of the following: sinful passions have no sources in the human nature created after the image and likeness of God. The sin is not ontological in the sense that it is not inherent in man organically. The sin is introduced from the outside when man recedes from God and from a divine plan about man. If to specify an ontological source of sinful passions, its location, exclusively external in relation to man, will also be wrong. However, the subject of 'demonic provocation' the tempting devil influences from the very beginning is present not only at Christianity, but also at the Abrahamic tradition in general. But the patristic doctrine about the struggle against passions highlights the aspect of interrelation of these external devil influences and an internal deviation of the unreasonable part of soul. These external influences are sometimes considered even as modifying internal deviations, but most of the external influence is considered inferior to the internal deviation. These external influences have always existed, but when the deviation from a divine plan about man is made in soul, these external influences start 'parasitizing' actively on this internal deviation and prove themselves in a much bigger degree. Thus, sinful passions hold a difficult and internally contradictory position in Christian anthropology. On the one hand, they are not primordial, not ontological, are not irreversible, connected with human nature. On the other hand, they are derivative of a human nature, but the nature which is already damaged by sin. This duality at Maximus Confessor 's works is designated as follows, 'the passion ... is abuse of natural action, and such an abuse of way of [natural] action appears when the movement inherent in any force [nature] goes to the unnatural ${ }^{116}$. But this duality is quite explainable if to take the circumstance into account that an ultimate goal of the patristic doctrine about the struggle against passions is not their final killing, but their correction, transformation.

As we already stated above, in patristical tradition the struggle against passions does not end in itself. This struggle is considered as a component of a more global process that is a deification of man. Certainly, it is an initial stage of this process, one of the first steps, but for the right understanding of this step it is necessary to recognize that the passionate power of his soulfinds salvation together with man as well. This force is improved and consecrated by the redirection of the passion energy from the corporal and sensual reality to the divine order reality. According to Maximus Confessor, such a transformation of the passionate part of human soul is considered as an implementation of an initial plan of God about man. This transformation represents the mysterious spiritual process, as a result of which a sensual-longing part of soul not only loses the power over man, but also improves and becomes 'normalized'.

'Because a truly great and marvelous work demanding a great attention and assiduity, and, first of all, with God's help, is able, firstly, to struggle against forces of a material pair inherent in [us] - I mean [forces] of anger and desire - and a division corresponding to them; also the one is blessed, who can direct them easily there where it will be necessary for mind, up to actively to be cleared by means of moral love of wisdom from initial thoughts ${ }^{17}$. Because the result of 
this refocusing with the physical reality to the divine is a genuine passion, the passion that deserves this naming is a passion for the divine. 'At whom mind always with God, and the desire develops into Divine passion, and all entirely rage turns into divine love. Thanks to a long-term communion with Divine inspiration, it (mind) becomes luminous, and, closely connected with its own passionate part, and turns it into a neverending divine passion and incessant love, having entirely addressed from terrestrial things to the Divine"18.

Maximus Confessor's statements concerning passion to divine, at first sight, contradict the ideas typical of the ascetic thought about the necessity of killing passions and achieving full impassivity. In Maximus Confessor's works impassivity is considered to be an immovability of the passionate part of human soul in relation to all that is against nature of man. Impassivity is necessary in relation to the sin, but not as a refusal of any activity in general. As for an orientation of the passionate part of soul to divine, here the speech about impassivity can not go.

Thus in Maximus Confessor's doctrine, human transformation contacts, first of all, the transformation of its passionate nature. At first, the passion is defined as a tool concept of the ascetic practice, there are single sinful passions demanding a self-victory. Then the passion is defined as a way of existence of our nature, as a condition of a suffering, a constant endurance of something; this suffering is inevitable for man because of creaturehood and limitation of the forces of our human nature.

In the context of the patristic divinity, similar passions' definitions do not indicate these or those certain features and characteristics of concrete forces of a human nature. It characterizes man as the being created from anything and imperfect, and therefore incomparable with the Divine nature which only one (unlike a creature) is free from any suffering. At the same time such a characteristic of 'passion' as inherent to people with 'perfect' suffering doesn't have any negative shade at all, is not relevant to the concept of fall in any way, but only describes man as changeable and created from 'anything'.

Furthermore, 'passion' is understood as a passionate part of soul dependent on mind as the anthropological natural component given by God to Adam's nature at the creation. This passionate part of soul is allocated by the Creator by forces of desire and anger. In human nature condition before the fall all these abilities and forces are characterized and estimated as benevolent by Maximus Confessor, as contained in an initial Divine plan about man, inherent in our natural Lagos and, therefore, aimed at a sacred selfrealization predetermined by the Creator in the achievement of deification. In the fallen nature of Adam they got an unnatural mode of existence, were distorted, merged with a sin, were closely interconnected with it through the passionate birth, and also in search of pleasure and through the flight from suffering. However, this passionate beginning of soul can be corrected and 'normalized' through its 'redirection' from a $\sin$ to Divine. It is achievable by an attainment of impassivity which is not abolition of natural passionate powers of soul in itself, but is got through refusal of their sinful aspiration.

Sometimes in Maximus Confessor's heritage the concept of passion is not defined as natural, but as some anthropological characteristic, namely, as an activity, the work of the human heart. Such a work can be normal, natural, corresponding to the Divine plan about man, and to our mission; but maybe the unnatural - sinful and ungodly.

Eventually, Maximus Confessor, concerning mystical divinity, symbolically identifies the concept of passion with the concept of deification. Here the sense of passion as suffering and endurance and passion as a 
natural internal-energy characteristic of the human nature extremely approach. In this case the endurance appears in especially positive sense as the 'patience' of influence of the fertile Divine gifts streaming to man. On the other hand, natural internal-energy of a human nature also proves here in an ideal sense that is a passionate tendency to God, to connection with Him.

1 John Meyendorff. Byzantine Theology: Historical

Trends and Doctrinal Themes. M, 2001, 249.

Maximus Confessor. Mystagogia // Writings of Reverend Maximus Confessor. M., 1993. Book I, 167-168.

Maximus Confessor. Questions to Thalassius 21 // Writings of Reverend Maximus Confessor. M., 1993.

J.-C.Larchet. Reverend Maximus Confessor is the intermediary between the East and the West. M., 2004, 120 p.

Maximus Confessor. Questions to Thalassius 21 // Writings of Reverend Maximus Confessor. M., 1993.

Maximus Confessor. Ambigua 7 // PG 91. Col. 1089 A.

Maximus Confessor. Ambigua 7 // PG 91. Col. 1089 A.

Aristotle, Nicomachean Ethics.1105 B 20

9 Reverend Ioann Damaskin. Exact exposition of the Orthodox faith. Book 2. 22: The passion (patience) and influence//Work of Reverend Ioann Damaskin. Istochnik znaniya. M., 2002. 217-218

10 Maximus Confessor. Ambigua // PG 91. 1073 B. Col. 61-62.

11 Galenus. De placitis Hippocratis et Platonis VI. 1.

12 Maximus Confessor. Ambigua // PG 91. Col. 1196 C - 1196 D.

13 Maximus Confessor. Questions and bewilderment. 41. St. Mount Athos, M., 2010, 101.

14 Aristotle, Nicomachean Ethics.1102 a 30

15 Aristotle, Nicomachean Ethics.1103 b.

16 Maximus Confessor. Questions to Thalassius 58 // Patristic. Church Fathers' writings and patrological researches. Nizhniy Novgorod, 2007, 53-54

17 Maximus Confessor. Ambigua // PG 91. Col. 1197 C - 1197 D.

18 Maximus Confessor. Centuries on Love 48 // Writings of Reverend Maximus Confessor. M., 1993. v. 1, 114.

\title{
Преображение человека
}

и борьба со страстями

в святоотеческом наследии

(концепция Максима Исповедника)

\author{
С.Н. Бельков \\ Русская христианская гуманитарная академия \\ Россия, 191023, Санкт-Петербург, \\ наб. $р$. Фонтанки, 15
}

\begin{abstract}
Касаясь темь мистической божественности Максим Исповедник символически объединяет концепт «страсти» с конщептом «теозис». Таким образом, смыслы страсти как страдания и претерпевания и как естественной внутренней энергии человека чрезвычайно сближаются друг с другом. С этой точки зрения особо позитивное значение приобретает терпеливость как способность выносить благодатные Божественные дары, обращенные к человеку. С другой стороны, и естественная внутренняя энергия человека также обретает позитивный смысл - как пассионарная направленность к Богу, к соединению с Ним.
\end{abstract}

Ключевые слова: Максим Исповедник, страдания и страсти, теозис.

Научная специальность: 23.00.00 - политология. 